УДК 902(571.63)

\title{
НИЖНИЙ СТРОИТЕЛЬНЫЙ ГОРИЗОНТ КРАСКИНСКОГО ГОРОДИЩА
}

\author{
(C) 2021 г. Е. И. Гельман
}

В статье опубликованы предварительные результаты изучения нижнего строительного горизонта Краскинского городища - центра округа столичной области государства Бохай (698-926 гг.). Памятник выполнял также функцию порта, который являлся морскими воротами Бохая. От его стен начинался морской путь в Японию. Рассматриваются строительные горизонты территории храмового комплекса, жилых кварталов и дороги. Соотнесены результаты изучения нижнего горизонта жилой застройки, нижнего горизонта дороги, ведущей к храмовой территории и фундамент стены, сооруженной из каменных блоков на начальном этапе строительства фортификационных сооружений. Нижний горизонт на Краскинском городище характеризуется как ранний этап его существования, когда оно еще было поселением. Характеризуются жилые и хозяйственные сооружения, а также другие основные элементы планировочной структуры памятника. Анализируются пространственная организация и плотность застройки на изученном участке городища. Систематизируются археологические материалы, связанные с ранним этапом заселения памятника. Рассматривается характер материальной и духовной культуры населения этого периода, представленный орудиями труда, вооружением, бытовыми изделиями, монетой Кайюань тунбао, украшениями, предметами игр, обломками керамики, черепицы и отходами металлообработки. Уточняется датировка нижней границы существования памятника и определяется его функция, как поселения земледельцев, рыбаков, охотников и собирателей, ремесленников. Предполагается, что уже в этот период на поселении был сооружен первый буддийский храм.

Ключевые слова: археология, Краскинское городище, государство Бохай (698-926 гг.), жилища, хозяйственные сооружения, дороги, храм.

\section{LOWER CONSTRUCTION HORIZON OF KRASKINO HILLFORT}

\section{E. I. Gelman}

This paper features the preliminary results of a study of the lower building horizon of the Kraskino hillfort. It was the center of a district of the capital region of the Bohai state (698-926). The site also operated as a port, which was the sea gate of Bohai. The sea route to Japan began from its walls. The author considers the buildings horizons of the temple complex territory, residential quarters and the road. This study intends to provide information on the correlation of the results of studying the lower horizon of residential buildings, the lower horizon of the road near the temple territory, and the foundation of a stone block wall built at the initial stage of the construction of fortifications. The lower horizon at Kraskino settlement is considered to belong to an early stage of its existence, when it was still a settlement. Residential and utility buildings, as well as other basic elements of the planning structure of the site are characterized. The spatial organization and building density of the hillfort are analyzed. Archaeological materials related to the early stage of the site's existence are systematized. The material and spiritual culture of the population of this period is considered, which is represented by tools, weapons, household items, Kaiyuan Tongbao coin, ornaments, game items, fragments of ceramics, roof tiles and metalworking waste. The dating of the lower boundary of the site's existence is specified, and its function is determined as a settlement of farmers, fishermen, hunters, gatherers, and artisans. It is assumed that the first Buddhist temple was built at the settlement as early as during the period in question.

Keywords: archaeology, Kraskino hillfort, Bohai state (698-926), dwellings, utility structures, roads, temple

\section{Введение}

Краскинское городище располагается на берегу бухты Экспедиции залива Посьета (Хасанский район, Приморский край) и правом берегу р. Цукановки (Яньчихэ) (рис. 1). Сведения о нем сохранились в летописных источниках как о центре округа Янь, входившего в столичную область Восточной столицы (Луньюаньфу) государства Бохай (698-
926 гг.). Городище имеет форму, близкую к прямоугольнику, с дугообразным северным валом, периметр которого достигает 1380 м, а площадь поверхности внутри валов составляет около 12,6 га (рис. 2). В настоящее время ширина вала по верху составляет 1 м, а в его основании - 10-12 м. Имеются трое ворот с защитными укреплениями, входы в них обращены в сторону моря. Городище являлось 


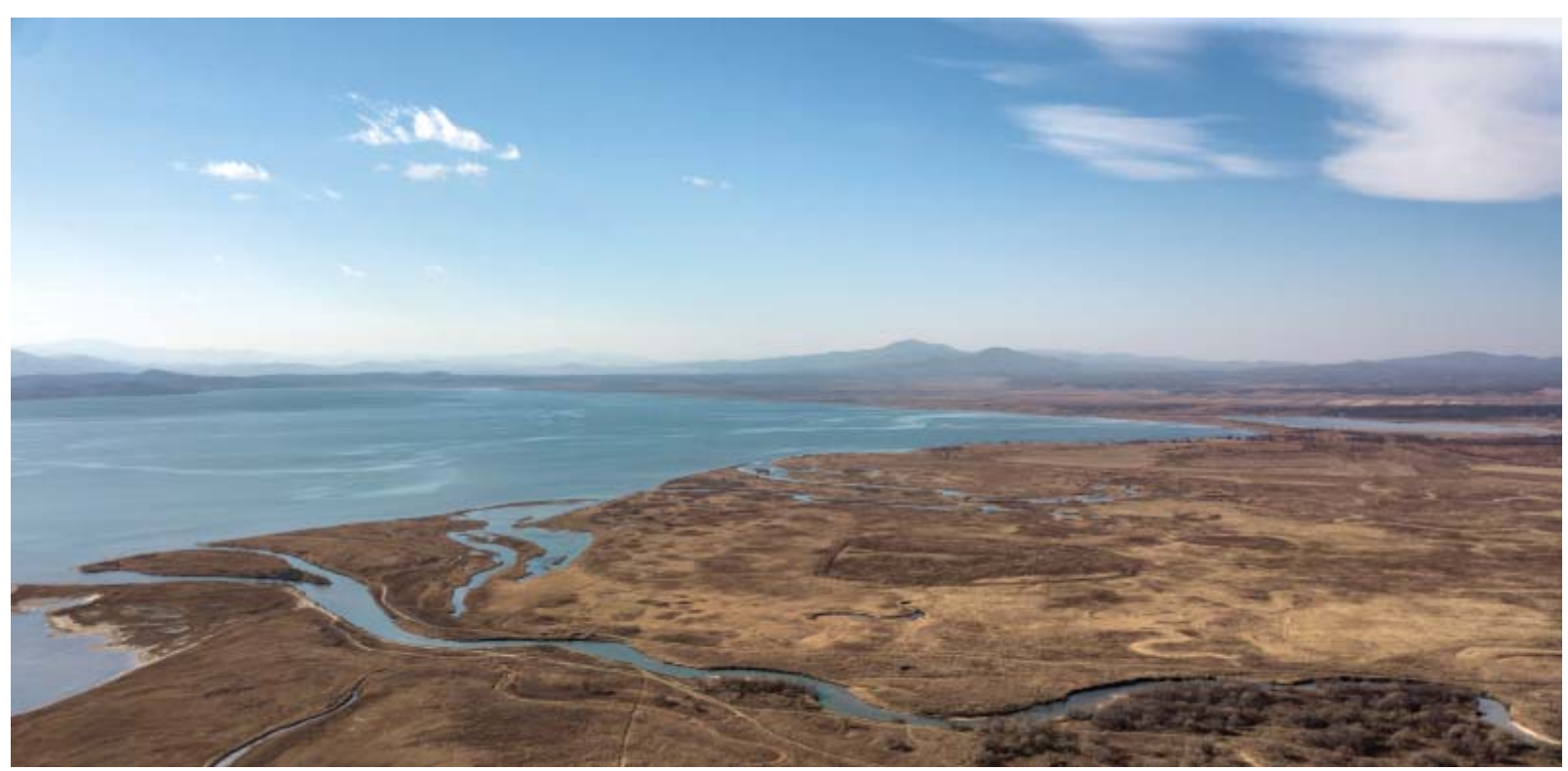

Рис. 1. Вид с востока на Краскинское городище на берегу бухты Экспедиции залива Посьета

Fig. 1. Eastern view of Kraskinskoye hillfort on the bank of the Expedition Bay of the Possiet Gulf

«морскими воротами» Бохая, откуда начинался морской путь к Японским островам (Ивлиев, 2005; Kojima, 2019).

Раскопки памятника ведутся с 1980 г. по настоящее время, что позволило изучить культурные отложения на разных участках и получить представление о функционировании средневекового города на разных этапах его существования (Государство Бохай, 1994; Болдин и др., 2001; Ивлиев, 2006; Города, 2018, с. 79-103). Выявлены 5-6 строительных горизонтов, содержащих разные типы жилых, хозяйственных и общественных сооружений, a также раскопаны защитные сооружения восточных ворот, к западу от городища обнаружена группа бохайских погребений (Болдин и др., 2008; Гельман и др., 2011, 2016, 2018, 2019; Гельман, 2018, с. 61-63). В настоящем исследовании обобщаются результаты анализа объектов и археологических материалов, относящихся к нижнему строительному горизонту Краскинского городища.

Основные элементы планировочной структуры поселения

Площадь всех раскопов, на которых удалось завершить исследования нижнего строительного горизонта, в совокупности составляет менее $700 \mathrm{~m}^{2}$ (рис. 3). Такая ситуация сложилась из-за высоких грунтовых вод на памятнике и трудности понимания стратиграфической ситуации на разных участках городища. Установить наличие пяти-шести строительных горизонтов вместо двух-трех ранее выявленных впервые удалось в 2007 г. (Болдин и др., 2008). С этого времени при каждой удачной климатической ситуации, в сухой сезон, который случается не каждый год, ведутся исследования слоев, связанных с ранним этапом заселения памятника. На полностью изученных участках были раскопаны важные объекты: отдельные участки ниже крепостной стены на ее северо-западном отрезке и на восточных воротах, часть дорог, жилища и хозяйственные сооружения. Предварительно определено место расположения самого раннего буддийского храма, которое предстоит еще исследовать.

О буддийском храме. Информация о наличии нескольких строительных горизонтов на памятнике появлялась постепенно, по мере изучения Краскинского городища. Сначала были изучены остатки центрального храма верхнего горизонта (Болдин, 1993). В дальнейшем на территории храмового комплекса были обнаружены остатки еще двух строительных горизонтов (рис. 4) (Болдин и др., 2001; Болдин, 2013). Самый нижний горизонт соотносится с нивелировочными отметками $-147 /-155$ см. Но длительное время связать периодизацию храмового комплекса со строительными горизонтами в жилых кварталах не удавалось. Только раскопки 2018 г. показали, что основание крепостной стены вблизи храма находится на уровне $-240 \mathrm{~cm}$, т. е. примерно на метр ниже, чем самый ранний строительный горизонт храмовых сооружений (Гельман и др., 2019-б, с. 200-203). Вместе с тем в отложениях дороги четвертого и пятого горизонтов содержались фрагменты плоской и полукруглой черепицы, обломки дисков фронтальной черепицы и украшений крыши храма. Пятый горизонт дороги нахо- 


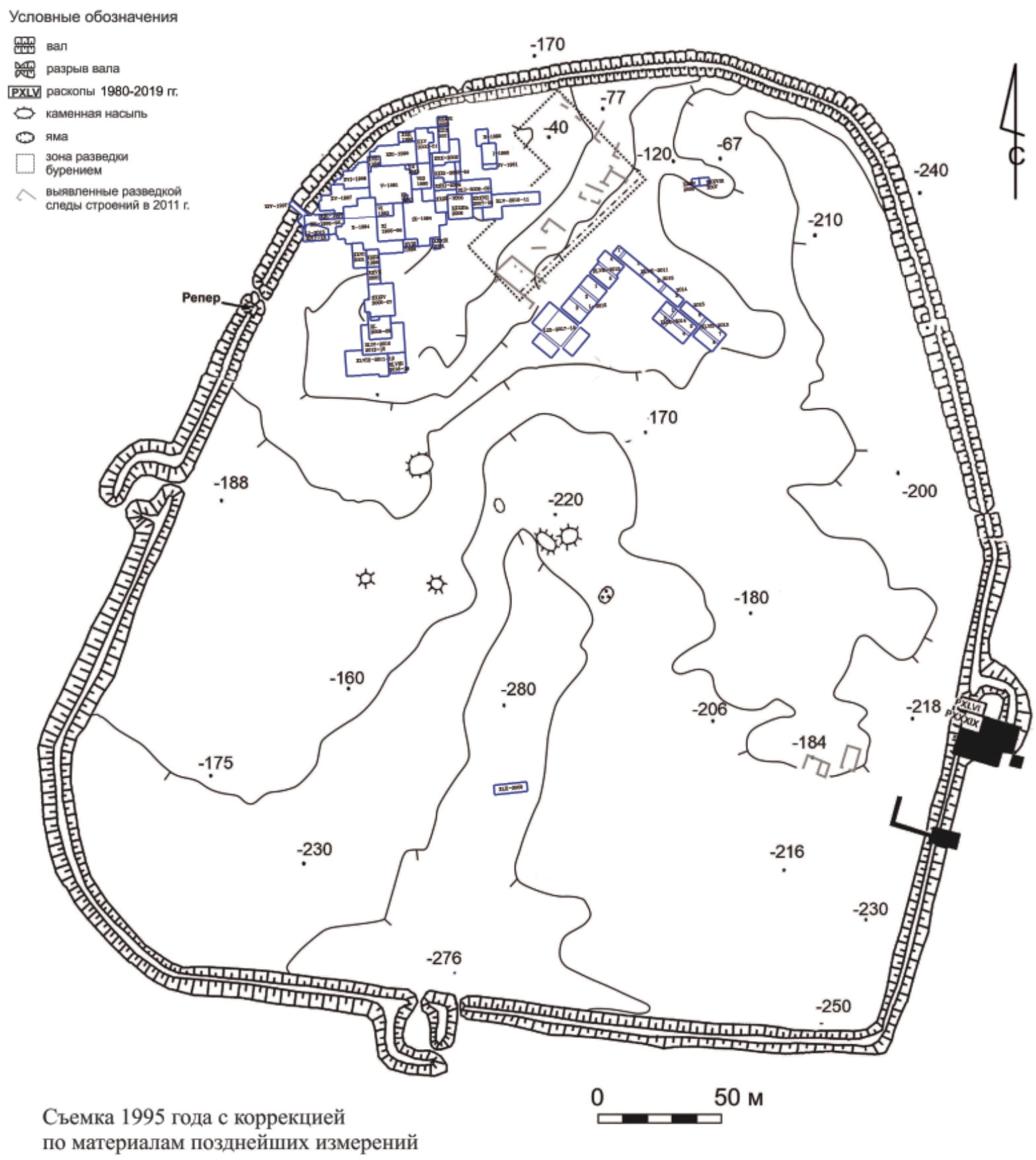

Рис. 2. План Краскинского городища

Fig. 2. Plan of Kraskinskoye hillfort

дится на уровне -258/-300 см, то есть почти на полтора метра ниже известных нам остатков наиболее ранней постройки храма. При изучении жилищ нижнего строительного горизонта Краскинского городища в 2007 г. были обнаружены обломки черепицы и украшений крыши храма, которые также позволяли предположить наличие более ранних остатков храмовых сооружений (Болдин и др., 2008).

Дороги. Благодаря раскопкам 2018 г. (раскоп LI) вблизи храмового буддийского комплекса (северо-западная часть городища) и крепостной стены изучен фрагмент дороги с остатками каменного покрытия самого нижнего пятого строительного горизонта (Гельман и др., 2019-б, с. 200-203). Было установлено, что в этот период на памятнике еще отсутствовали крепостные стены, а на месте города сначала существовало поселение. Этот участок дороги, пролегавшей вдоль ограды между городскими кварталами и храмовым комплексом, является наиболее сохранившимся, особенно в верхних горизонтах. Ее направление указывает на то, что в нижнем строительном горизонте она проходила в юго- 


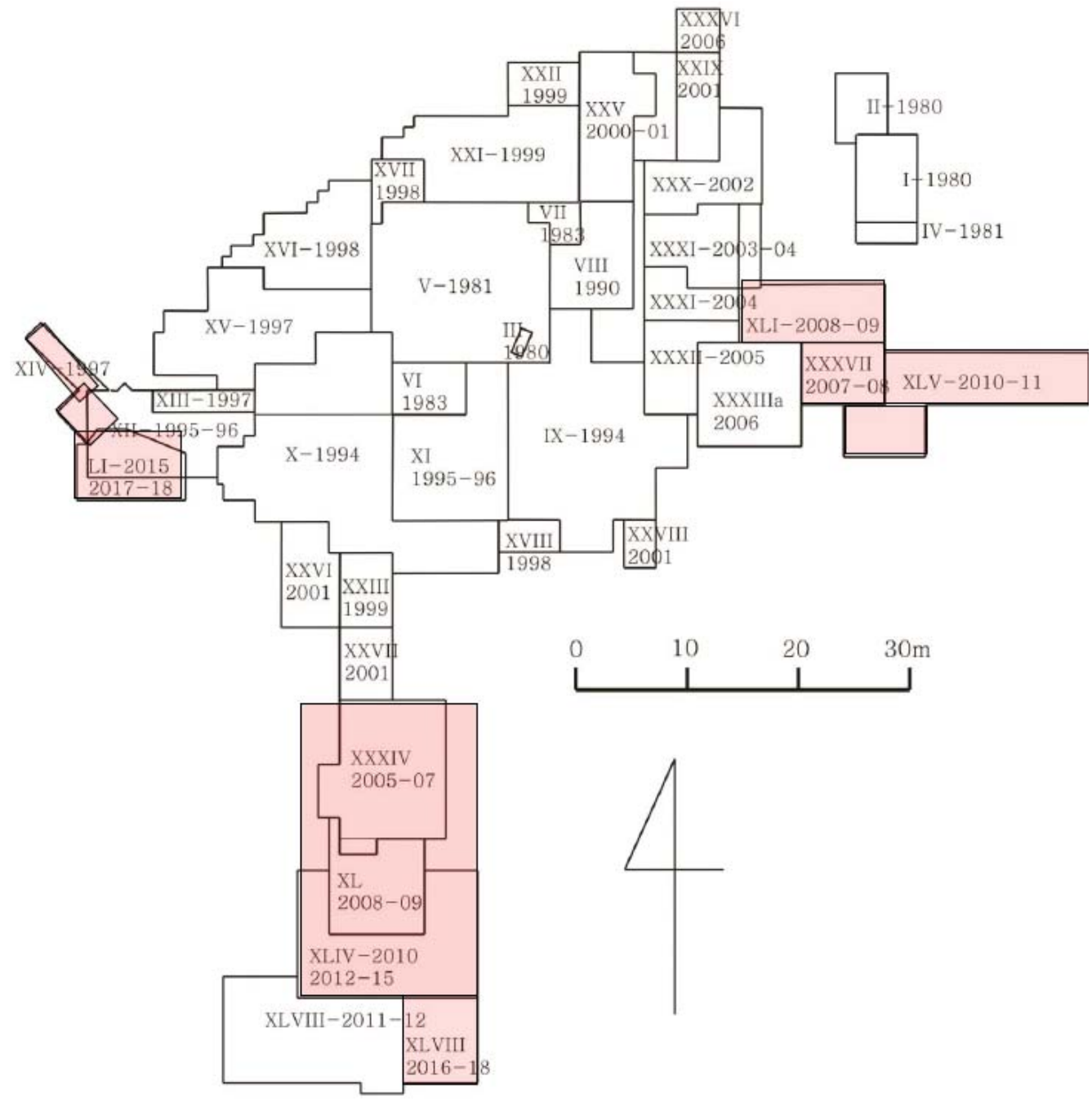

- участкн с полностью нзученнымн культурнымн отложеннямн

Рис. 3. Ситуационный план северо-западной части городища с раскопанными участками (римскими цифрами обозначены номера раскопов, арабскими - год раскопок)

Fig. 3. Dimensional plan of the north-western portion of the hillfort with excavated areas (Roman numerals indicate the excavations number, Arabic numerals - the excavation year)

западном направлении под валом, а в северо-восточном вела на территорию храмового комплекса (рис. 5). Ширина дороги составила 3,9-4,2 м. Мощность отложений дорожного полотна этого горизонта составила 40-45 см. Она сооружалась тем же способом, что и остальные отложения дороги верхних четырех строительных горизонтов. На песчаную подсыпку утрамбовывались камни средних размеров, между которыми забутовывался мелкий камень или мелкая галька с песком. По мере разрушения дорога подсыпалась песком, строительным мусором и хозяйственными отходами (зола древесного и каменного угля, кости животных, створки раковин моллюсков и прочее). На данном участке дороги самым массовым материалом, который использовался в ремонте дороги, была черепица.
В центре северной части памятника (раскоп XLVII) в жилом квартале начато изучение поверхности небольшого участка дороги, проходившей в направлении север - юг. В верхних четырех горизонтах дорога имела каменное покрытие, но на поверхности пятого горизонта такое покрытие отсутствовало. Следы плотной забутовки шириной около 3 метров в том же направлении, что и верхние уровни дороги, дают основание предположить, что на самом раннем этапе дорога в этом месте была грунтовой. Однако полностью завершить работу по ее изучению не удалось из-за высоких грунтовых вод.

Жилища и хозяйственные сооружения. В северо-западной части городища изучены полностью остатки двух жилищ, несколько жилищ раскопаны частично, обнаружены 

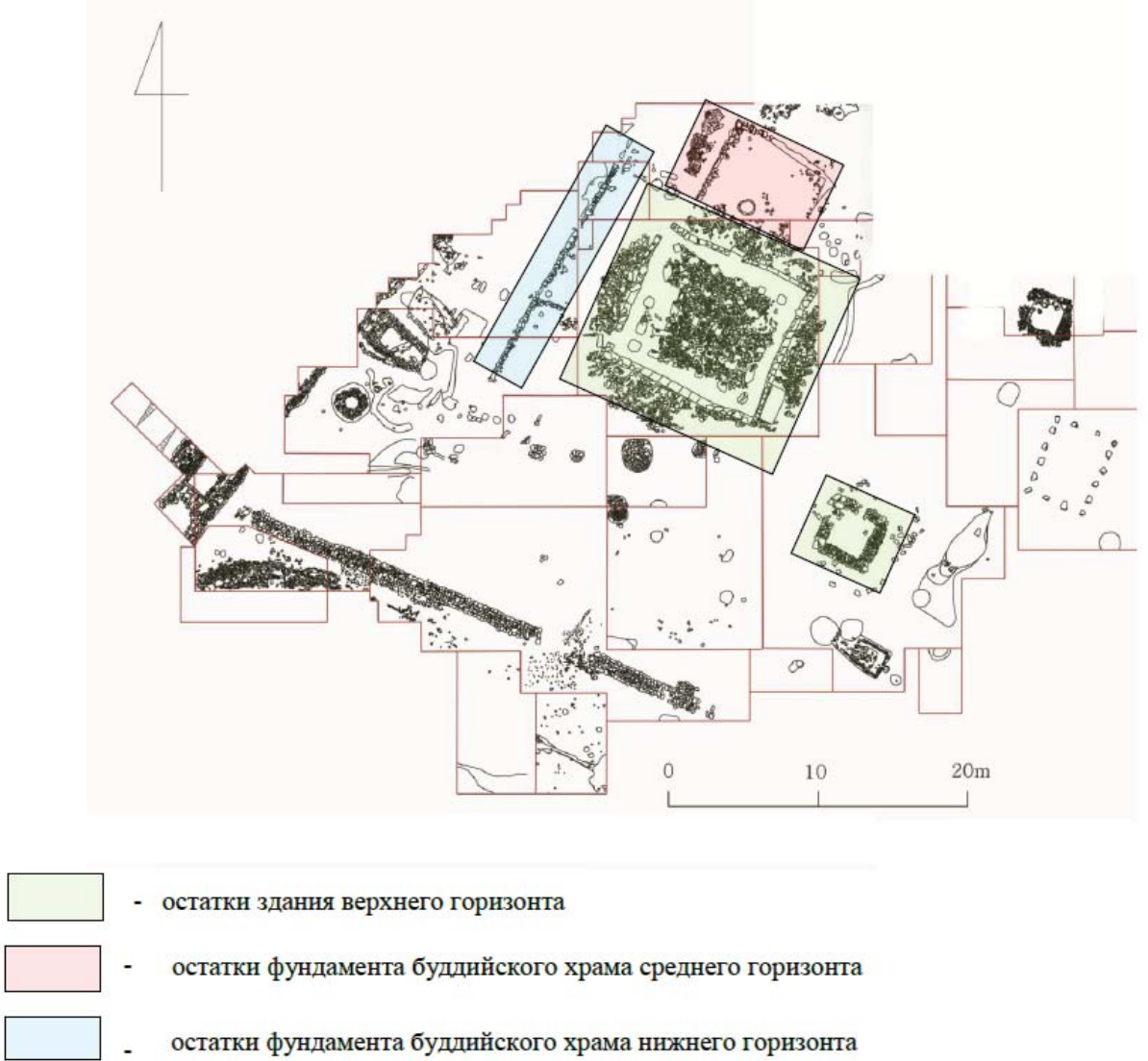

Рис. 4. План с указанием расположения объектов храмового комплекса на городище, участка крепостной стены и прилегающих участков

Fig. 4. Plan marking the location of the temple complex sites at the hillfort, a section of the fortress wall and the adjacent areas

многочисленные хозяйственные сооружения. Bсе жилища нижнего горизонта независимо от степени их изученности представлены полуземлянками глубиной около полуметра (45-55 см) (рис. 6). Размеры жилищ составили: жилище $6\left(5 \times 4\right.$ м) - около 20 м $^{2}$ (Болдин и др., 2008), жилище $12(3,5 \times 4,5$ м) - 15,7 м² (Болдин и др., 2008; Гельман и др., 2011-а), жилище 28 $(5,5 \times 3,5$ м) - 19 м (Гельман и др., 2015, 2019б). Из-за высокой переувлажненности почвы (супесей и песков) в нижнем горизонте размеры очага удалось установить только в жилище 12 , диаметр которого составил около 1 м. В этом же жилище, которое погибло от пожара, сохранились столбовые ямки. Ориентировка жилищ, в тех случаях, когда это можно было определить, была разнообразной: север - юг, запад - восток, юго-запад - северо-восток. В нескольких жилищах была выявлена обмазка глиной пола, отдельные куски карбонизированной древесины (остатки конструкций) и в двух случаях использование камня для основания стен.

Хозяйственные сооружения различаются по размеру и их положению относительно дневной поверхности (углубленные и назем- ные). Обнаружены хозяйственные ямы внутри жилищ. Такие ямы могли устраиваться как вплотную к стенкам котлована жилища, так и ближе к очагу. Их размеры: диаметр 1 м и глубина 0,5 м (жилище 12 и котлован жилища в раскопе XLV) (Гельман и др., 2011). В них обнаружены обломки и целые сосуды, остатки костей животных, периостракум мидий. Назначение ям внутри жилищ нижнего горизонта могло быть разнообразным, в том числе и для хранения продуктов. Результаты раскопок жилищ из других строительных горизонтов свидетельствуют о разных формах, размерах и назначении хозяйственных ям внутри жилищ, в некоторые из ям ставились крупные сосуды для хранения воды (Гельман и др., 2018).

Рядом с жилищем 12 обнаружены 2 объекта, которые в совокупности образуют хозяйственный дворик без видимых признаков ограды (Гельман и др., 2011). Котлован подпрямоугольной формы $(2,50 \times 2,1$ м, глубиной до $55 \mathrm{cm)} \mathrm{и} \mathrm{хозяйственная} \mathrm{яма,} \mathrm{овальная}$ в плане $(1,8 \times 1,7$ м, глубиной до 30 см), сгорели и были заполнены обгоревшей обмазкой и обломками круговой посуды. Сохранившиеся 


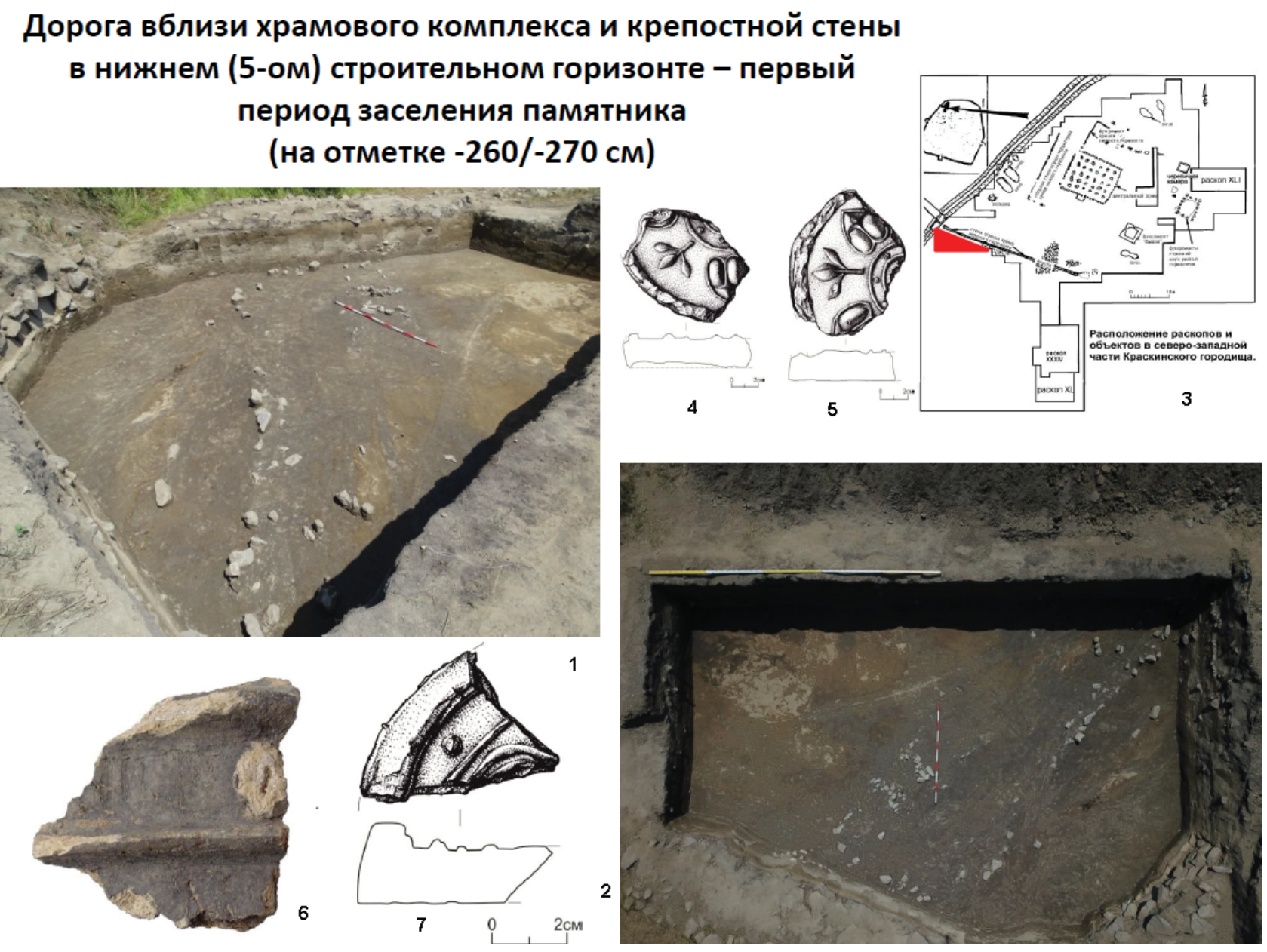

Рис. 5. Дорога на Краскинском городище в нижнем строительном горизонте и артефакты, собранные в ее заполнении: 1 - вид с юго-запада на остатки дороги; 2 - вид сверху на остатки дороги, фрагменты дисков кровельной черепицы и украшения; 3 - план-схема с указанием расположения объектов храмового комплекса

(красным цветом обозначен участок раскопа с остатками изученной дороги); 4, 5, 7 - фрагменты дисков полукруглой фронтальной черепицы; 6 - фрагмент декоративного украшения крыши

Fig. 5. The road at Kraskinskoye hillfort in the lower construction horizon and artifacts collected in its filling material: 1 - southwest view of the remains of the road; 2 - top view of the remains of the road, fragments of roofing tile discs and decorations; 3 - diagram indicating the locations of temple complex sites (with the excavation site and the remains of the studied road marked in red); 4, 5, 7 - fragments of the disks of semicircular frontal tiles;

6 - fragment of roof decoration

несколько ямок от столбов, возможно, использовались для сооружения навеса над ямами. Общий размер хозяйственного дворика условно составил около $80 \mathrm{~m}^{2}$. Расстояние до другого жилища нижнего горизонта составило 6 м, а свободная от хозяйственных объектов территория между двумя жилищами составляет примерно 50-70 м². Плотность расположения жилищ и размер хозяйственных двориков примерно соответствуют и следующему этапу заселения памятника в границах раскопанных участках. Эти цифры могут в будущем измениться после существенного увеличения площади раскопок нижнего строительного горизонта. Кроме того, нельзя исключать, что хозяйственные сооружения могли использоваться совместно с родственниками из соседних домохозяйств.
Рядом с жилищем 28 (раскоп XLVIII, восточный сектор) обнаружен наполовину раскопанный котлован округлой формы диаметром около 1,92 м и глубиной 0,8 м. В заполнении были обнаружены фрагменты керамической посуды, монета, серп и др. артефакты, кости млекопитающих и моллюсков. Возможно, другие хозяйственные объекты находятся за пределами раскопа.

Наземные хозяйственные постройки изучены только частично, поэтому об их размерах судить сложно, можно лишь отметить их прямоугольную/квадратную форму. В некоторых случаях они немного заглублены (например, котлован в раскопе XLIV, 2014 г., имеет размеры 2,6×2,4 м и глубину до 10 см). Их заполнение включало фрагменты керамиче- 


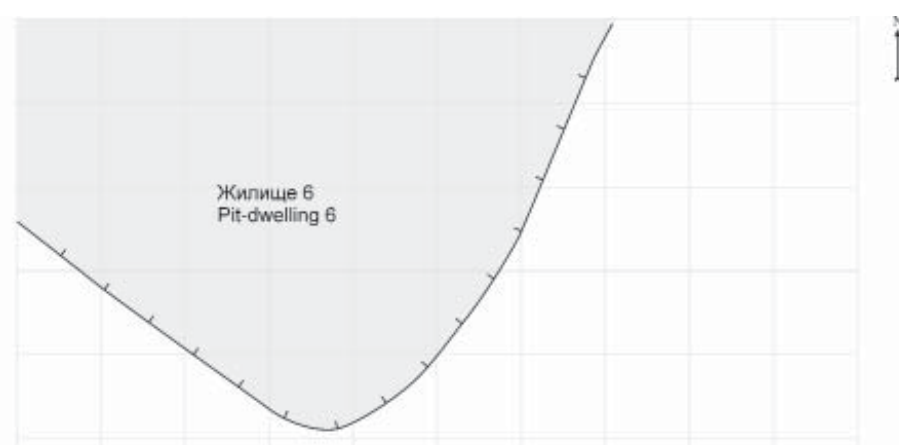

Рис. 6. Планы остатков жилищ 6 и 12 , хозяйственных сооружений из нижнего строительного горизонта

Краскинского городища

Fig. 6. Plans of the remains of dwellings 6 and 12, utility structures from the lower construction horizon of Kraskinskoye hillfort

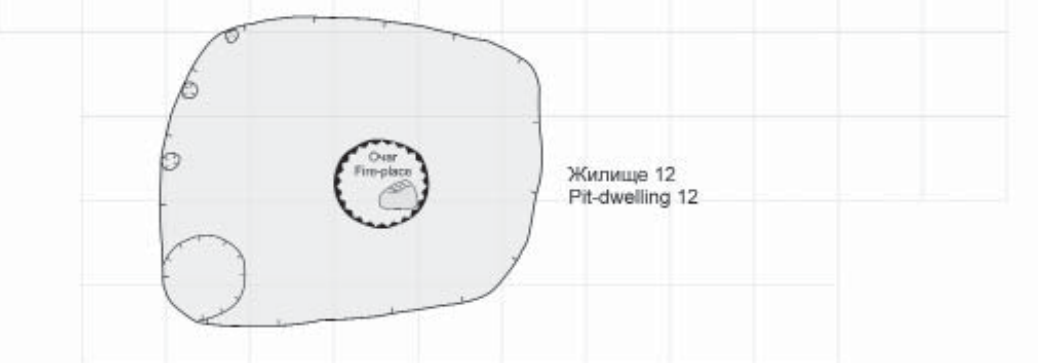

Xos nua

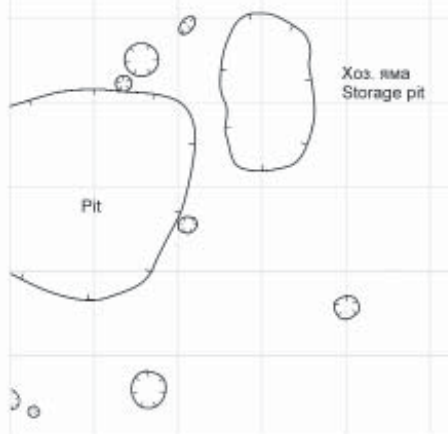

ских сосудов, костей животных, рыб и другие кухонные остатки.

Материальная культура.

Набор артефактов, обнаруженный в нижнем горизонте Краскинского городища в разных объектах (табл. 1), в значительной степени совпадает с теми, что мы встречаем в верхних четырех горизонтах ${ }^{1}$. Можно заключить, что основа материальной культуры Бохая в бассейне p. Туманган сложилась уже на самом раннем этапе становления государства. В этот период времени мохэский компонент (Пискарева, 2019), судя по Краскинскому городищу, представлен незначительно по сравнению с другими территориями Бохая, вошедшими в

его состав позднее (рис. 7, 8). Вместе с тем керамика мохэского облика сохраняется в небольшом количестве и в материалах других периодов городища. Кроме того, она встречается вместе с обломками посуды с морфологическими особенностями, характерными для ольгинской культуры (мелкоячеистая выбивка, насечки по краю венчика).

Судя по орудиям труда и обилию фрагментов криц во всех объектах нижнего горизонта, а также многочисленным железным изделиям, население памятника занималось сельским хозяйством, добычей и обработкой металла (железа и чугуна), ювелирным делом, производством керамики и черепицы, ткачеством, 


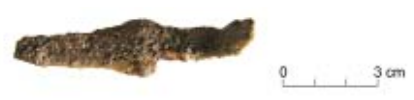

1

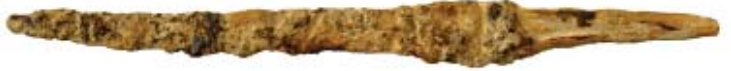

2
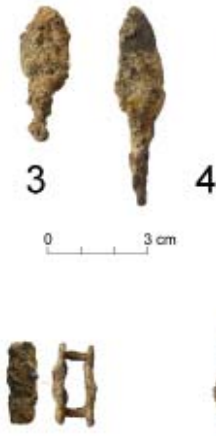

$0 \quad 3 \mathrm{~cm}$

9

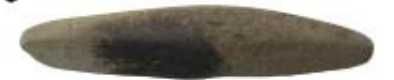

14

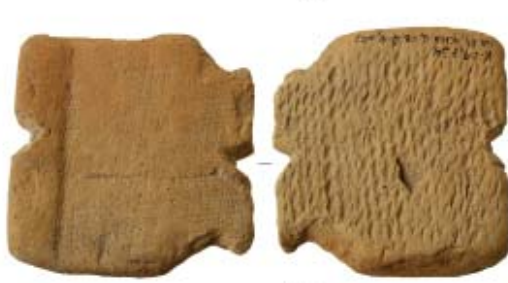

15
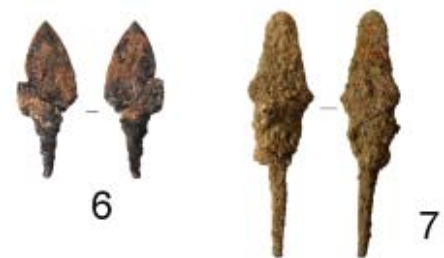

7

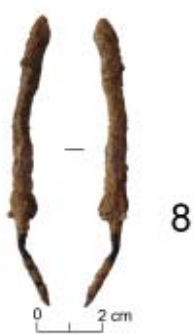

10
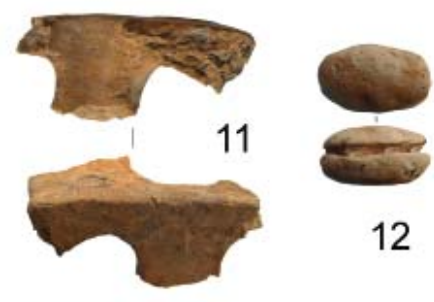

12

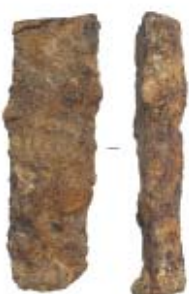

13

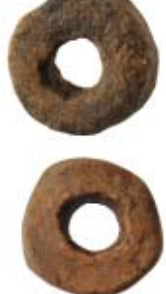

16

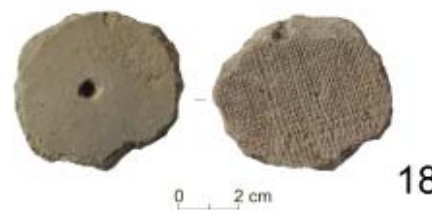

17
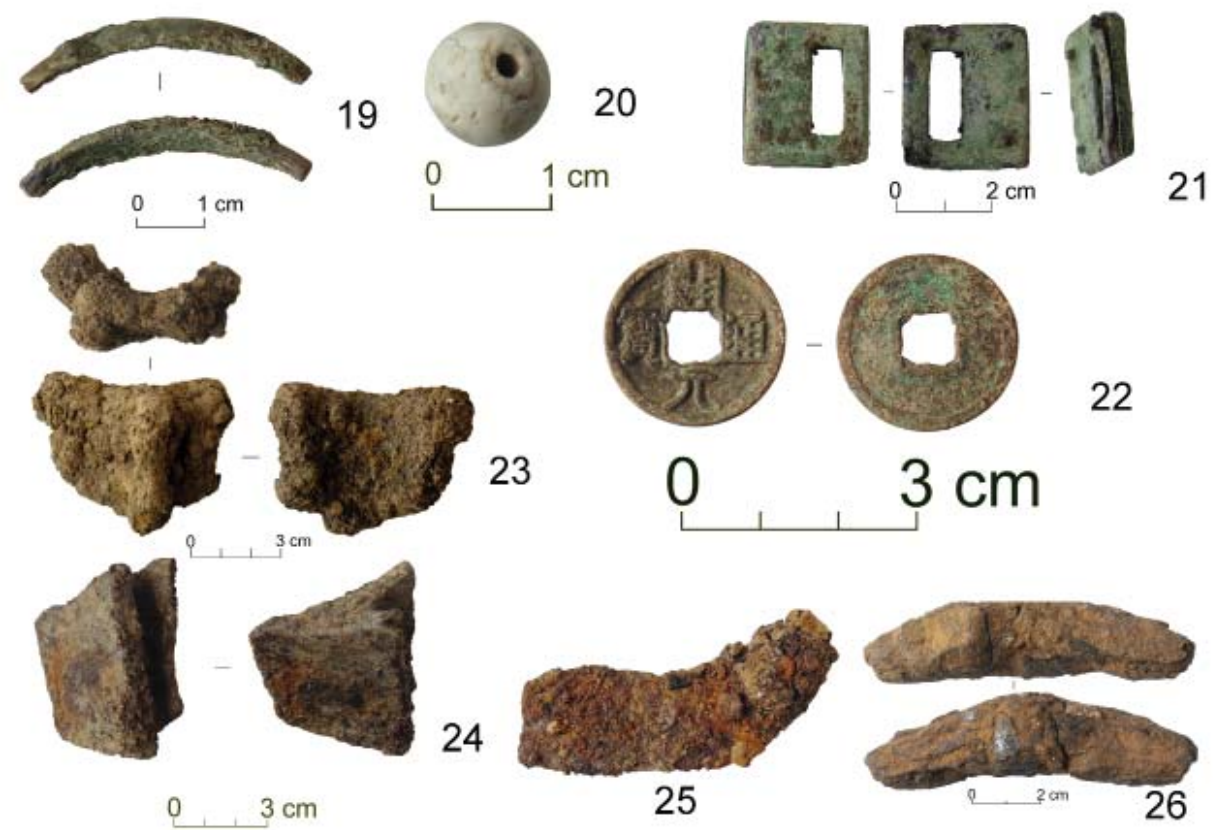

21

Рис. 7. Предметы, найденные в нижнем строительном горизонте: 1, 2 - ножи; 3, 4, 6-8 - наконечники стрел; 9 - обоймица; 10 - кольцо; 11 - фрагмент «бохайского кубика» с отверстиями; 12, 15 - грузила; 13 - фрагмент ножки котла; 14 - точило; 16, 17 - кольца; 18 - заготовка пряслица; 19 - фрагмент браслета; 20 - бусина; 21 - поясная накладка; 22 - монета Кайюань тунбао; 23 - обломок втулки ступицы колеса; 24 - фрагмент лемеха; 25 - фрагмент серпа; 26 - головка ювелирного молотка (1-10, 25, 26 - железо; 11,12,15-18 - глина; $19,21,22$ - бронза, 23, 24 - чугун)

Fig. 7. Items found in the lower construction horizon: 1, 2 - knives; 3, 4, 6-8 - arrowheads; 9 - clip; 10 - ring; 11 fragment of a "Bohai cube" with holes; 12, 15 - sinkers; 13 - boiler leg fragment; 14 - sharpener; 16, 17 - rings; 18 - spindle blank; 19 - bracelet fragment; 20 - bead; 21 - a belt overlay; 22 - Kaiyuan tongbao coin; 23 - wheel hub fragment; 24 - ploughshare fragment; 25 - sickle fragment; 26 - jewelry hammer head (1-10, 25, 26 - iron; 11, 12, 15-18 - clay; 19, 21, 22 - bronze; 23, 24 - cast iron) 

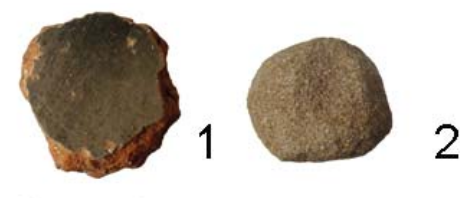

0

$2 \mathrm{~cm}$
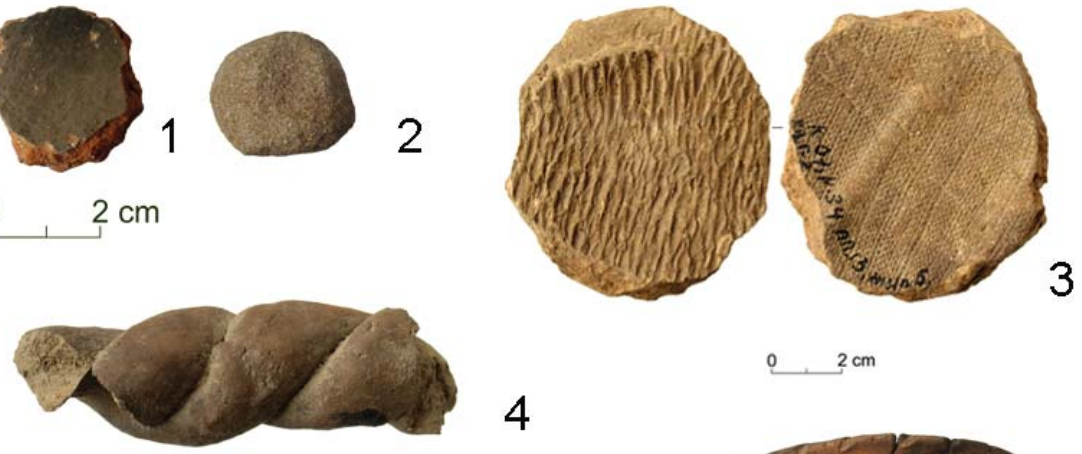

4
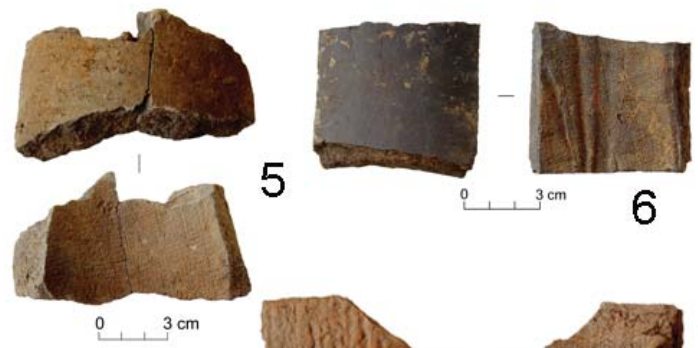

$0,2 \mathrm{~cm}$
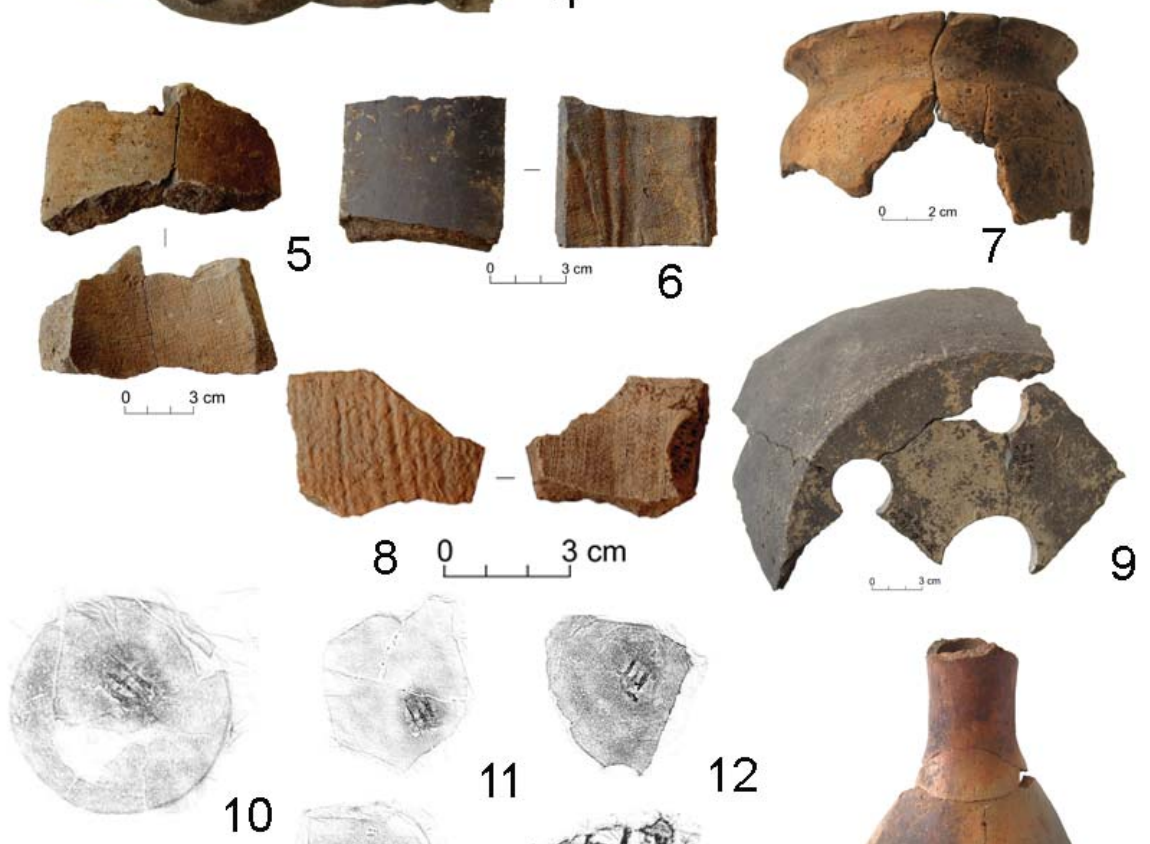

11

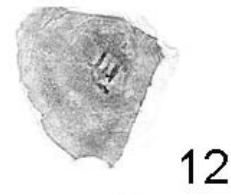

12
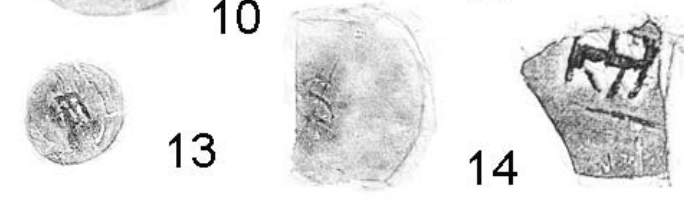

15
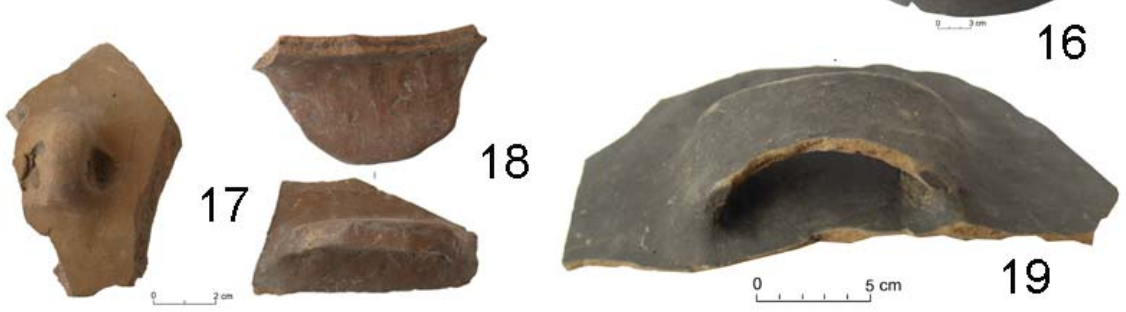

Рис. 8. Керамические изделия из нижнего строительного горизонта: 1, 2 - игральные фишки; 3 - диск, изготовленный из черепицы; 4 - декоративное украшение крыши храма; 5,6,8 - фрагменты полукруглой черепицы; 7 - часть горшка; 9 - обломок пароварки; 10-15 - прорисовки иероглифических знаков с днищ сосудов (вне масштаба); 16 - нижняя часть сосуда-подставки; 17-19 - фрагменты петельчатой, козырьковой и горизонтально-ленточной ручек сосудов

Fig. 8. Ceramic items from the lower construction horizon: 1,2 - playing chips; 3 - disc made of tiles; 4 - temple roof decoration; 5,6,8 - fragments of semicircular tiles; 7 - fragment of a pot; 9 - fragment of a steamer; 10-15 - drawings of hieroglyphic signs from vessel bottoms (not to scale); 16 - lower part of a support vessel; 17-19 - fragments of looped, visor and horizontal ribbon handles of vessels

охотой и рыболовством, морским собирательством. Жители поселения уже были знакомы с игрой «гону», которая позднее стала еще популярнее. Игральные фишки, изготовленные из обломков керамических сосудов, черепицы и камня (песчаника), встречаются почти во всех объектах нижнего строительно- го горизонта. Образцы изобразительно-декоративного искусства также имеют аналогии с артефактами других периодов (Асташенкова, 2010).

В жилищах и хозяйственных сооружениях на первом этапе существования памятника собраны фрагменты черепицы и изготов- 
Таблица 1. Распределение артефактов в объектах нижнего строительного горизонта Table 1. Distribution of artefacts across the sites of the lower construction horizon

\begin{tabular}{|c|c|c|c|c|c|c|c|}
\hline & Типы артефактов & $\begin{array}{l}\text { Жилище } 6 \\
\text { (раскоп } \\
\text { XXXIV) }\end{array}$ & $\begin{array}{l}\text { Жилище 12, } \\
\text { хозяйствен- } \\
\text { ные } \\
\text { сооружения } \\
\text { (раскопы } \\
\text { XXXIV, XL) }\end{array}$ & $\begin{array}{l}\text { Жилище 28, } \\
\text { хозяйствен- } \\
\text { ные } \\
\text { сооружения } \\
\text { (раскопы } \\
\text { XLIV, XL- } \\
\text { VIII) } \\
\end{array}$ & $\begin{array}{l}\text { Котлован } \\
\text { жилища } \\
\text { (раскоп } \\
\text { XLV) }\end{array}$ & $\begin{array}{l}\text { Фрагмент } \\
\text { жилища, } \\
\text { хозяйствен- } \\
\text { ные } \\
\text { сооружения } \\
\text { (раскоп } \\
\text { XLIV) } \\
\end{array}$ & $\begin{array}{l}\text { Дорога } \\
\text { (раскоп } \\
\text { LI) }\end{array}$ \\
\hline \multirow{4}{*}{$\begin{array}{c}\text { Орудия } \\
\text { труда }\end{array}$} & Нож & + & + & + & + & + & \\
\hline & $\begin{array}{l}\text { Ювелирный } \\
\text { молоток }\end{array}$ & & + & & & & \\
\hline & Серп & & & + & & & \\
\hline & Чугунный лемех & & + & + & & & \\
\hline \multirow{6}{*}{$\begin{array}{l}\text { Воору- } \\
\text { жение }\end{array}$} & $\begin{array}{l}\text { Заготовка костяного } \\
\text { свистунка }\end{array}$ & + & & & & & \\
\hline & $\begin{array}{l}\text { Черешковый } \\
\text { листовидный } \\
\text { наконечник стрелы } \\
\end{array}$ & + & + & + & & + & \\
\hline & $\begin{array}{l}\text { Черешковый } \\
\text { ромбовидный } \\
\text { наконечник стрелы }\end{array}$ & & & + & & & \\
\hline & $\begin{array}{l}\text { Черешковый } \\
\text { долотовидный } \\
\text { наконечник стрелы }\end{array}$ & & & & + & & \\
\hline & $\begin{array}{l}\text { Черешковый } \\
\text { иволистный } \\
\text { наконечник стрелы }\end{array}$ & & & & & & \\
\hline & Панцирная пластина & & & & & & \\
\hline \multirow{15}{*}{$\begin{array}{c}\text { Бытовые } \\
\text { предметы }\end{array}$} & Обоймица & + & & + & & + & \\
\hline & Пробой & + & & & & & \\
\hline & Гвозди & + & & + & & + & + \\
\hline & Скоба & & & + & & & \\
\hline & Железное кольцо & & & & & + & \\
\hline & Железный крючок & & & & & + & \\
\hline & $\begin{array}{l}\text { Фрагменты } \\
\text { чугунных котлов } \\
\end{array}$ & & + & + & & + & + \\
\hline & $\begin{array}{l}\text { Втулки колеса } \\
\text { (чугун) }\end{array}$ & & & & & + & \\
\hline & Чека колеса (чугун) & & & & & + & \\
\hline & Точила (камень) & + & & + & & + & \\
\hline & $\begin{array}{l}\text { Грузила (камень, } \\
\text { глина) }\end{array}$ & + & & & + & & \\
\hline & $\begin{array}{l}\text { Кольца-грузики } \\
\text { (глина) }\end{array}$ & + & + & + & & + & \\
\hline & $\begin{array}{l}\text { «Бохайские кубики» } \\
\text { (глина) }\end{array}$ & & & + & & + & + \\
\hline & $\begin{array}{l}\text { Шарики (глина, } \\
\text { камень) }\end{array}$ & + & & & & & \\
\hline & $\begin{array}{l}\text { Пряслица (глина, } \\
\text { камень) }\end{array}$ & & & + & & & \\
\hline Монеты & & & & + & & & \\
\hline \multirow{3}{*}{$\begin{array}{c}\text { Украше- } \\
\text { ния }\end{array}$} & Браслеты (бронза) & & & + & & & \\
\hline & Поясная накладка & & & + & & & \\
\hline & $\begin{array}{l}\text { Бусины (камень, } \\
\text { глина) }\end{array}$ & & & + & & & \\
\hline
\end{tabular}




\begin{tabular}{|c|c|c|c|c|c|c|c|}
\hline $\begin{array}{l}\text { Предметы } \\
\text { для игр }\end{array}$ & $\begin{array}{l}\text { Игральные фишки } \\
\text { (изготовлены из } \\
\text { стенок сосудов, } \\
\text { черепицы, камня) }\end{array}$ & + & + & + & & + & + \\
\hline \multirow{4}{*}{$\begin{array}{l}\text { Черепица, } \\
\text { украшения } \\
\text { крыши }\end{array}$} & $\begin{array}{l}\text { Черепица } \\
\text { полукруглая }\end{array}$ & & & & + & + & \\
\hline & Черепица плоская & + & + & & & + & \\
\hline & $\begin{array}{l}\text { Диски фронтальной } \\
\text { черепицы }\end{array}$ & & & & & & + \\
\hline & $\begin{array}{l}\text { Декоративные } \\
\text { украшения крыши }\end{array}$ & + & & & & & + \\
\hline
\end{tabular}

ленные из них предметы (игральные фишки, грузило, пряслица), что предполагает наличие здания с черепичной крышей и декоративными украшениями. К таким зданиям относятся дворцовые и административные сооружения, судя по раскопкам бохайских столиц (Сун, 2018). На Краскинском городище пока не обнаружено ни одного административного здания с черепичной крышей, возможно также, что в нижнем строительном горизонте оно отсутствовало совсем из-за невысокого статуса в виде поселения. Вместе с тем значительное количество черепицы (674 фрагмента/24,638 кг), украшения крыши и диски фронтальной черепицы в заполнении дороги нижнего горизонта, рядом с территорией храмового комплекса, убедительно свидетельствуют о том, что и в ранний период храмовая постройка располагалась на том же месте, где обнаружены остатки фундаментов верхних строительных горизонтов городища. Кроме того, концевые диски и обломки декоративных украшений аналогичны образцам, обнаруженным в верхних отложениях храмового комплекса (Асташенкова, Болдин, 2004; Асташенкова, 2010, 2019a, 2019б). Судя по стратиграфическим наблюдениям, храм из нижнего горизонта использовался задолго до строительства крепостной стены и обслуживал духовные потребности населения поселения до получения им высокого статуса центра одного из округов Восточной столицы. Именно с этим фактом следует связать начало строительства фортификационных сооружений.

\section{Заключение}

На изученной площади памятника пока раскопано мало жилищ нижнего строительного горизонта, но можно предположить, судя по их ориентировке, что строгой планировки на поселении еще не было. Площадь жилищ в среднем составляла 15-20 м². Они представляли собой полуземлянки с очагами и хозяйственными ямами, пол обмазывался глиной. Рядом с жилищами располагались наземные и углубленные хозяйственные сооружения, образующие хозяйственные дворики. Некоторые из них имели навесы-крыши. Застройка была свободнее, чем в последующие этапы функционирования Краскинского городища.

Образцы материальной культуры населения раннего этапа существования памятника имеют полное сходство с аналогичными артефактами разных категорий из верхних строительных горизонтов. Это свидетельствует о формировании основы бохайской культуры уже в начальный период становления государства, вероятно, до сложения административно-территориальной системы в Бохае. Мохэский и другие компоненты в культуре населения Краскинского городища в его ранних отложениях представлены статистически незначительно.

Находки черепицы разных типов, декоративных украшений крыши указывают на то, что буддизм проник на территорию южной части Приморья задолго до того, когда он стал «официальной» религией в Бохае. Его роль в жизни населения памятника была гораздо выше, чем мы могли предполагать ранее. Вместе с буддизмом шире распространялась письменность (Ивлиев, 2014). Часть населения была грамотной, китайские иероглифы и их подобия встречаются даже на керамических сосудах, в том числе на доньях, что можно рассматривать как клейма частных мастеров. В других строительных горизонтах они не встречаются, сохраняются только тамгообразные знаки и надписи на стенках керамической посуды.

Оценивая датировку нижнего горизонта, необходимо иметь в виду, что начало международных отношений с Японией и обмен посольствами с Бохаем приходится на конец 1-й трети VIII в. Это повлекло за собой получение Краскинским городищем нового статуса и строительство фортификационных сооружений. Учитывая стратиграфическую ситуацию, можно предположить, что поселение на месте 
будущего центра округа Яньчжоу просуществовало довольно долго, не менее нескольких десятилетий, то есть на рубеже VII-VIII вв. Дальнейшие исследования позволят уточнить нижнюю хронологическую границу для памятника. Но нужно иметь в виду, что выбор бохайцами этого места для строительства морского порта и отправки посольств в
Японию не был случаен. Местные жители были хорошими рыбаками и моряками, имели навыки мореплавания и, очевидно, знали морские маршруты. Сведения о посещении мохэсцами Японских островов сохранились в японских хрониках (Kojima, 1996), не исключено, что некоторые такие путешествия совершались из залива Посьета.

\section{Примечание:}

${ }^{1}$ Керамика специально не рассматривается в статье, так как в силу обширности задачи является объектом отдельного исследования. Можно лишь отметить, что все формы сосудов нижнего горизонта встречаются в более поздних отложениях памятника.

\section{ЛИТЕРАТУРА}

Асташенкова Е.В., Болдин В.И. Декор концевых дисков Краскинского городища // Россия и АТР. 2004. №1(43). C. 122-129.

Асташенкова Е.В. Предметы изобразительного и декоративно-прикладного искусства Краскинского городища // Бохай: история и археология. Владивосток, 2010. С. 81-85.

Aсташенкова E.В. Декоративно-прикладное искусство населения Краскинского городища // Мультидисциплинарные исследования в археологии. 2019а. №2. С. 62-81.

Асташенкова Е.В. Символы богатства и власти в искусстве бохайского и чжурчжэньского населения (по данным археологических раскопок приморских памятников) // Труды Института истории, археологии и этнографии ДВО РАН. 2019б. Т.25. С.189-222.

Болдин В.И., Гельман Е.И., Ивлиев А.Л., Никитин Ю.Г. Интеграция на Краскинском городище: 4 года исследований //Вестник ДВО РАН. 2001. № 3. С. 74-91.

Болдин В.И. Буддийский храм Краскинского городища // Проблемы этнокультурной истории Дальнего Востока и сопредельных территорий. Благовещенск, 1993. С. 49-59.

Болдин В.И. Исследование храмового буддийского комплекса на Краскинском городище в Приморье // Буддизм Ваджраяны в России: Исторический дискурс и сопредельные культуры. М., 2013. С. 131-135.

Болдин В.И., Гельман Е.И., Лещенко Н.В. Отчет об археологических исследованиях на Краскинском городище Приморского края в 2007 г. Сеул, 2008. Кор. и русс. яз.

Гельман Е.И. Бохайский город в российской истории: от архимандрита Палладия до наших дней. Ойкумена. Регионоведческие исследования. 2018. № 1 (44). С. 60-72.

Гельман Е.И., Асташенкова Е.В., Болдин В.И., Ивлиев А.Л., Лещенко Н.В., Ким Ын.К., Кан Ин Ук. Археологические исследования российско-корейской экспедищии на Краскинском городище в Российском Приморье в 2009 году. Фонд изучения истории Северо-Восточной Азии, Институт истории, археологии и этнографии народов Дальнего Востока ДВО РАН. Сеул, 2011. Т. І, Т. ІІ. Кор. и русс. яз.

Гельман Е.И., Асташенкова Е.В., Пискарева Я.Е., Бессонова Е.А., Зверев С.А. Мультдисциплинарные исследования бохайской группы погребений в окрестностях Краскинского городища // Археология, этнография и антропология Евразии. 2016. №4. С. 94-101.

Гельман Е.И., Асташенкова Е.В., Пискарева Я.Е., Санафеев А.Ю., Ким Ын Кук., Чжун Сук Бэ. Археологические исследования на Краскинском городище в Приморском крае России в 2015 году. Сеул, 2018. Кор. и русс. яз.

Гельман Е.И., Асташенкова Е.В., Пискарева Я.Е., Ким Ын Кук, Чжун Сук-Бэ. Археологические исследования на Краскинском городище в Приморском крае России в 2018 году. Фонд изучения истории Северо-Восточной Азии, Институт истории, археологии и этнографии народов Дальнего Востока ДВО РАН: Сеул, 2019. 631 с. Кор. и русс. яз.

Государство Бохай (698-926 гг.) и племена Дальнего Востока России. М., 1994. 219 с.

Города средневековых империй Дальнего Востока / Колл. авторов. Е.В. Асташенкова, С.Е. Бакшеева, Е.И. Гельман, И.В. Гридасова, А.Л. Ивлиев, Н.А. Клюев, Н.Н. Крадин, Я.Е. Пискарева, С.Д. Прокопец, Е.А. Сергушева. М. : ИВЛ, 2018. 367 с.: ил.

Ивлиев А.Л. Очерк истории Бохая // Российский Дальний Восток в древности и средневековье: открытия, проблемы, гипотезы. Владивосток: Дальнаука, 2005. С. 449-475. 
Ивлиев А.Л. Исследования Краскинского городища и археологическое изучение Бохая в Приморье // Россия и АТР, 2006, №3(53). С. 5-18.

Ивлиев А.Л. Эпиграфические материалы Бохая и бохайского времени из Приморья // Россия и АТР, 2014, №4(86). С. 207-217.

Пискарева Я.Е. Мохэский компонент в бохайской культуре (по материалам Краскинского городища) // Мультидисциплинарные исследования в археологии, 2019, №2. С. 104-122.

Сун, Юйбинь. Исследование остатков столичных городов Бохая // Мультидисциплинарные исследования в археологии. 2018. №2. С. 103-125.

Kojima, Yoshitaka. The history of relation between Mohe, Bohai and Japanese Islands. In: The First International Symposium of Bohai Culture (To the 1300 anniversary of the foundation of Bohai state). Vladivostok. 1996. Pp. 22-28.

Kojima, Yoshitaka. An archaeological study about the road network of Bohai // Мультидисциплинарные исследования в археологии. 2019. №2. Рр. 51-60. Англ.яз.

\section{Информация об авторе:}

Гельман Евгения Ивановна, кандидат исторических наук, доцент, ведущий научный сотрудник, заведующая сектором, Институт истории, археологии и этнографии народов Дальнего Востока ДВО РАН (г. Владивосток, Россия); gelman59@mail.ru

\section{REFERENCES}

Astashenkova, E. V., Boldin, V. I. 2004. In Rossiya i ATR (Russia and Asia-Pacific Region) 43 (1), $122-129$ (in Russian).

Astashenkova, E. V. 2010 In Ivliev, A. L. (ed.). Bokhai: istoriia i arkheologiia (v oznamenovanie 30-letiia s nachala arkheologicheskikh raskopok na Kraskinskom gorodishche (Bohai: history and Archaeology (Commemorating 30 Years Since the Beginning of Archaeological Excavations of Kraskinskoye Hillfort)). Vladivostok: Institute of History, Archaeology and Ethnography of the Peoples of the Far-East, Far-Eastern Branch of the RAS, 81-85 (in Russian).

Astashenkova, E. V. 2019a. In Mul'tidistsiplinarnye issledovaniia v arkheologii (Multidisciplinary Studies in Archaeology) (2), 62-81 (in Russian).

Astashenkova, E. V. 2019b. In Trudy Instituta istorii, arkheologii i etnografii DVO RAN (Proceedings of the Institute of History, Archaeology and Ethnology FEB RAS) (25), 189-222 (in Russian).

Boldin, V. I., Gelman, E. I., Ivliev, A. L., Nikitin, Yu. G. 2001. In Vestnik Dal'nevostochnogo Otdeleniya RAN (Vestnik of Far Eastern Branch of Russian Academy of Sciences) 3, 74-91 (In Russian).

Boldin, V. I. 1993. In Sapunov, S. B. (ed.). Problemy etnokul'turnoi istorii Dal'nego Vostoka i sopredel'nykh territorii (Issues of the Ethnic-cultural History of the Far East and Adjacent Territories). Blagoveshchensk: Blagoveshchensk State Pedagogical University, eshhensk, 49-59 (in Russian).

Boldin, V. I. 2013. In Leont'eva, E. V. (ed.). Buddizm Vadzhraiany v Rossii: istoricheskii diskurs $i$ sopredel'nye kul'tury (Vajrayana Buddhism in Russia: Historical Discourse and Adjacent Cultures). Moscow: "Almaznyi Put' Publ., 131-135 (in Russian).

Boldin, V. I., Gel'man, E. I., Leshhenko, N. V. 2008. Otchet ob arkheologicheskikh issledovaniiakh na Kraskinskom gorodishche Primorskogo kraia v 2007 g. (Report on Archaeological Studies at the Kraskinsky Settlement of Primorsky Krai in 2007). Seul (in Korean, in Russian).

Gel'man, E. I. 2018. In Oikumena. Regionovedcheskie issledovaniia (Ojkumena. Regiona Studies) 44 (1), 60-72 (in Russian).

Gel'man, E. I., Astashenkova, E. V., Boldin, V. I., Ivliev, A. L., Leshhenko, N. V., Kim, Yn. K., Kan, In Uk. 2011. Arheologicheskie issledovaniia rossiisko-koreiskoi ekspeditsii na Kraskinskom gorodishhe $v$ Rossiiskom Primor'e v 2009 godu (Archaeological Studies of the Russian-Korean Expedition at Kraskino hillfort in the Russian Primorye in 2009). 1. Vladivostok, Seul: Foundation for the Study of the History of Northeast Asia; Institute of History, Archaeology and Ethnography of the Peoples of the Far-East, Far-Eastern Branch of the RAS (in Korenian, in Russian).

Gel'man, E. I., Astashenkova, E. V., Boldin, V. I., Ivliev, A. L., Leshhenko, N. V., Kim, Yn. K., Kan, In Uk. 2011. Arheologicheskie issledovaniia rossiisko-koreiskoi ekspeditsii na Kraskinskom gorodishhe v Rossiiskom Primor'e v 2009 godu (Archaeological Studies of the Russian-Korean Expedition at Kraskino hillfort in the Russian Primorye in 2009). 2. Vladivostok, Seul: Foundation for the Study of the History of Northeast Asia; Institute of History, Archaeology and Ethnography of the Peoples of the Far-East, Far-Eastern Branch of the RAS (in Korenian, in Russian). 
Gelman, E. I., Astashenkova, E. V., Piskareva, Ya. E., Bessonova, E. A., Zverev, S. A. 2016 In Arkheologiia, etnografiia i antropologiia Evrazii (Archaeology, Ethnology \& Anthropology of Eurasia) 4, 94-101 (in Russian)

Gel'man, E. I., Astashenkova, E.,V., Piskareva, Ya.E., Sanafeev, A. Yu., Kim Yn Kuk., Chzhun Suk Bje. 2018. Arkheologicheskie issledovaniia na Kraskinskom gorodishche v Primorskom krae Rossii v 2015 godu (Archaeological Studies at Kraskinsky hillfort in Primorsky Krai of Russia in 2015.). Seul: Foundation for the Study of the History of Northeast Asia (in Korenian, in Russian).

Gel'man, E. I., Astashenkova, E. V., Piskareva, Ya. E., Kim Yn Kuk, Chzhun Suk-Bje. 2019. Arhkeologicheskie issledovaniia na Kraskinskom gorodishche v Primorskom krae Rossii v 2018 godu (Archaeological Studies at Kraskinsky hillfort in Primorsky Krai of Russia in 2018). Vladivostok, Seul: Foundation for the Study of the History of Northeast Asia; Institute of History, Archaeology and Ethnography of the Peoples of the Far-East, Far-Eastern Branch of the RAS (in Korenian, in Russian).

Shavkunov, E. V. 1994. (ed.). Gosudarstvo Bokhai (698-926 gg.) i plemena Dal'nego Vostoka Rossii (Bohai State (698-926) and the Tribes of the Russian Far East.). Moscow: "Nauka" Publ. (in Russian).

Kradin, N. N. 2018. (ed.). Goroda srednevekovykh imperiy Dal'nego Vostoka (Towns of the Medieval Empires of the Far East). Moscow: "Vostochnaya literatura" Publ. (in Russian).

Ivliev, A. L. 2005. In Andreeva, Zh. V. (ed.). Rossiiskii Dal'nii Vostok v drevnosti i srednevekov'e: otkrytiia, problemy, gipotezy (The Russian Far East in Antiquity and the Middle Ages: Discoveries, Issues, Hypotheses). Vladivostok: "Dalnauka" Publ., 449-475 (in Russian).

Ivliev, A. L. 2006. In Rossiya i ATR (Russia and Asia-Pacific Region) 53 (3), 5-18 (in Russian).

Ivliev, A. L. 2014. In Rossiya i ATR (Russia and Asia-Pacific Region) 86 (4), 207-217 (in Russian).

Piskareva, Ya. E. 2019. In Mul'tidistsiplinarnye issledovaniia v arkheologii (Multidisciplinary Studies in Archaeology) (2), 104-122 (in Russian).

Sun, Jujbin. 2018. In Mul'tidistsiplinarnye issledovaniia v arkheologii (Multidisciplinary Studies in Archaeology) (2), 103-125 (in Russian).

Kojima, Yoshitaka. 1996. In The First International Symposium of Bohai Culture (To the 1300 anniversary of the foundation of Bohai state). Vladivostok, 22-28 (in English).

Kojima, Yoshitaka. 2019. In Mul'tidistsiplinarnye issledovaniia v arkheologii (Multidisciplinary Studies in Archaeology) (2), 51-60 (in English).

\section{About the Author:}

Gel'man Evgeniia I. Candidate of Historical Sciences, Associate Professor, Institute of History, Archaeology and Ethnography of the Peoples of the Far East of the Far Eastern Branch of the Russian Academy of Sciences. Pushkinskaya St., 89, Vladivostok, 690001, Russian Federation; gelman59@mail.ru

Статья поступила в журнал 01.04.2021 г. Статья принята к публикации 01.04.2021 г. 